\title{
The chain impact of customers' value on organizational performance: A customer-based perspective in a command economy
}

\author{
Hosseini Mirzahassan* and Farideh Hosseini Imani \\ Business Administration Department University of Payam-e Noor, Po. Box: 19395-4697, Tehran, Iran.
}

Accepted 19 July, 2013

\begin{abstract}
This study assesses how customer value has chain effects on an insurance company's market orientation, competitive advantage and organizational performance in a command economy. In this study we want to analyze Iran's Insurance policy in strategy selection to identify its deficiencies compared to the ideal situation that Zhou explained in his essay, "Market orientation, competitive advantage and organizational performance: A demand- based perspective", done in hotel industry. He showed if a firm knows its customers well, the firm will be able to adopt an adaptable strategy "customer orientation or competitor orientation" in the market. The findings showed if Iran's insurance company perceives its customers as service sensitive, it tend will to develop customer orientation in order to satisfy its customers. But if it thinks its customers are price sensitive, it tends to develop no purposeful orientation. Moreover, the greater this firm's customer orientation, the more the firm is able to develop a competitive advantage based on innovation and market differentiation. In contrast, a competitor orientation has no special effect on the firm's differentiation advantages. Finally, innovation and market differentiation advantages in this company are not in the line with market performance (e.g., perceived quality, customer satisfaction) but increase in market performance will lead to higher financial performance (e.g., profit, market share).
\end{abstract}

Key words: Customer value, market orientation, competitive advantage, organizational performance.

\section{INTRODUCTION}

Thinking in terms of the market, not marketing is essential in the highly competitive arenas of today (Slater and Narver, 1994a). Nearly fifty years ago, marketers began to recognize the importance of adapting their market offerings to the shifting tastes, preferences, and desires of consumers (Keith, 1960); and nowadays customer value management (CVM) helps organizations to know their customers well, to identify their values, to give them better services and finally to develop profitable relationships with them. A firm is a long-term project and customer is the best representative of its health in every moment. Moreover customer will exhibit the firm's future performance. From this view, understanding what customers value within a given product or service, creating the recognized value for them, and then managing them are essential for businesses to select the adaptable strategies and to achieve success .Without knowing what customers actually value, firms cannot define and deliver a value proposition to satisfy them (Desarbo et al., 2001).

A market orientation involves a dual focus on both customers and competitors (Day and Nedungadi, 1994; Kohli and Jaworski, 1990, 1993; Slater and Narver, 1990, 1994b; Webster, 1994). It involves (1) the systematic 
gathering of information on customers and competitors, both present and potential, (2) the systematic analysis of the information for the purpose of market knowledge and (3) the systematic use of such knowledge to guide strategy recognition (Hunt and Morgan, 1995). According to these definitions the prerequisite for selecting the best market orientation (customer orientation or competitor orientation) is market knowledge that can be gained by analyzing customer value. In this article customer value is defined as what customers emphasize and desire in their preferences. In essence, customer value involves a compromise between customers' judgments of a product or service overall excellence (e.g., quality) against the sacrifice (e.g., price) needed to obtain the product (Desarbo et al., 2001). In assessing a firm's offering, service-emphasis customers are primarily concerned with the utilities they hope to receive. In contrast, price emphasis customers mainly pay attention to the price and other resources (e.g., time) they must give up to obtain the product (Zeithaml, 1988). Building on customer-based perspective and in a command economy, this paper examines how customer value emphasis affects and determines a firm's adoption of a customer versus a competitor orientation in Iran's insurance.

How a firm achieves and maintains a competitive advantage has aroused great attention in the strategy literature. There are two dominant competing perspectives: The first one is competitive force perspective which suggests industry structure and a firm's strategic positioning, the fundamental driver of competitive advantage (Porter, 1985). The next one is the resourcebased view (RBV). It suggests that competitive advantage stems from a firm's unique assets and inimitable capabilities (Barney, 1991). Although these two views differ sharply on how competitive advantage is achieved, they both focus primarily on firm's supply dimension of interactions and largely neglect the demand environment in which these interactions take place; however a fruitful strategy would be to explore how firms adapt their strategies in response to heterogeneous customer values for achieving competitive advantage (Adner and Zemsky, 2006). Now, this study by taking a demand-based perspective (customer based perspective) analyzes how customer value heterogeneity has chain effects on market orientation, competitive advantage and performance.

Hunt and Morgan (1995) define planned or command economies as cooperation among state-owned firms under the direction of a central planning board and market based economies as competition among self-directed, privately owned firms. This essay wants to test the conceptual model in Iran insurance which is a command economy to recognize either its competencies or deficiencies in strategy selection. Although these premises, taken individually, have been discussed by others at numerous times in many places, this article is the first to place them in a cohesive framework.
The main problems that this essay wants to analyze are whether the basis of strategy selection in Iran insurance is customer value, whether both customer and competitor orientation strategies will lead to competitive advantage and whether innovation and market differentiation advantages are in line with market and financial performance. The main objective of this study is to identify the chain impact of customer value on organizational performance in a command economy. The next objectives of this study are as follows: 1) to identify the impact of customer value on market orientation 2) to identify the impact of market orientation on competitive advantage 3) to identify the impact of competitive advantage on market performance 4) to identify the impact of market performance on financial performance.

\section{LITERATURE REVIEW}

\section{Customer value and market orientation}

When a firm's customers are service-centered, their primary attention in assessing the product or service value is the utilities they receive. In such a market, a firm must analyze its customers and develop a sufficient understanding of its target customers in order to deliver superior value to those customers (Desarbo et al., 2001).To compete on the delivery of superior customer value, a firm should be able to answer four basic questions: "(1) What exactly do customers value? (2) Of all the things customers value, which ones should we focus on to achieve advantage? (3) How well do customers think we deliver that value? (4)How will what customers value change in the future?" (Woodruff, 1997). A firm is not able to answer these questions unless it monitors its customers closely, gains information about them and then delivers the superior customer value by translating customer's preferences into firm`s strategies (Figure 1).

Because service-sensitive customers' perceptions of a product utilities change over time, a firm must investigate the changing preferences of these customers continuously and adjust its offerings accordingly. In other words, customer orientation is necessary to reach and satisfy service-conscious customers (Zhou et al., 2008). Customers' service emphasis may also lead to a greater level of competitor orientation. By having a clear understanding of the strengths and weaknesses of key current and potential competitors, the firm can better recognize its competitive position and develop a special product and services in order to position itself effectively among the competitors ( $\mathrm{Li}$ and Calantone, 1998). Second, because customers' needs are dynamic, a firm can attempt to anticipate changing customer preferences by monitoring the successes and failures of its competitors (Porter, 1985). Therefore, 


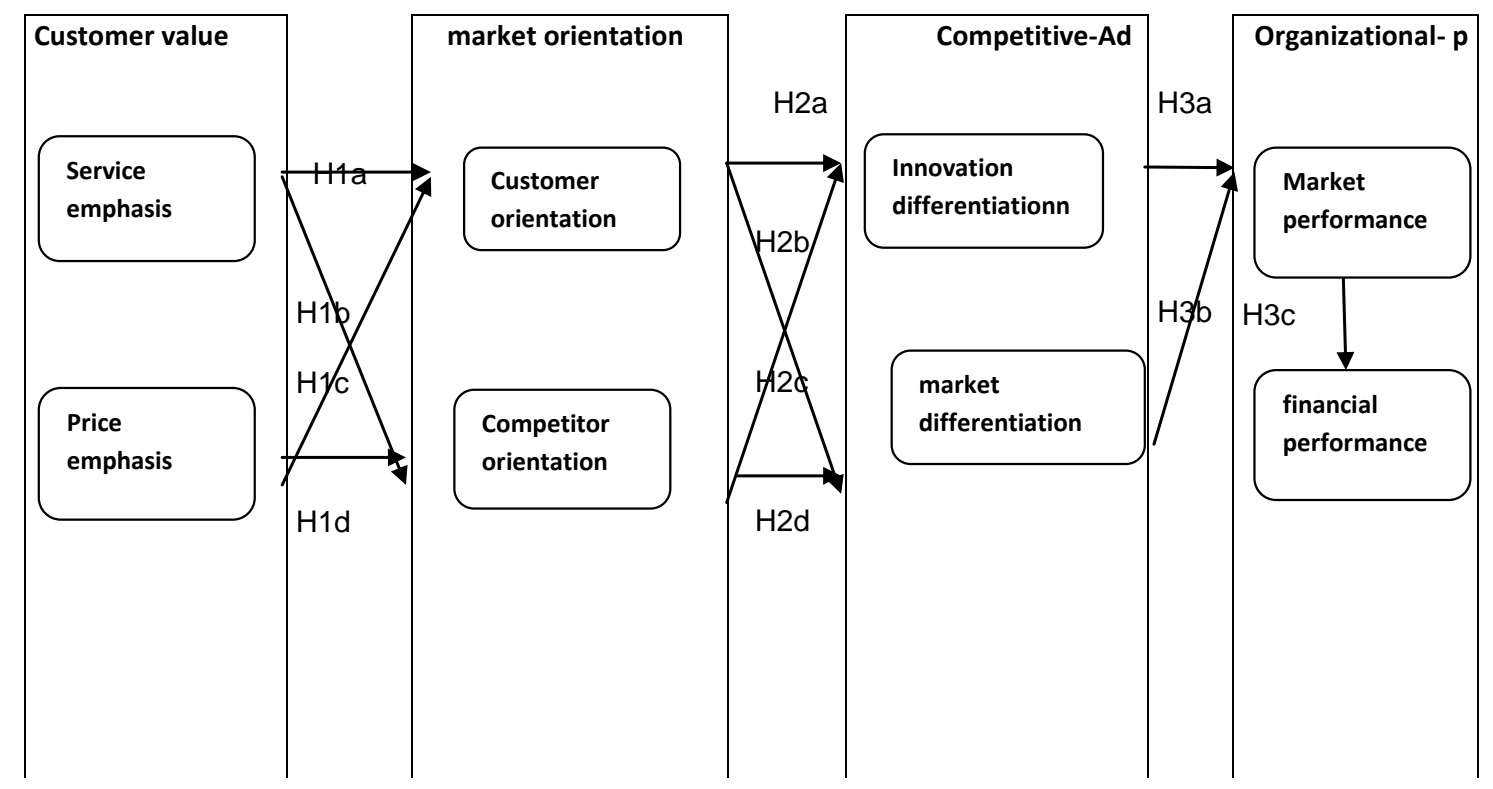

Figure 1. The conceptual model. Source: Zhou KZ. Market orientation, competitive advantage and performance (2008).

H1a: customers' service emphasis is effective on adoption of customer orientation strategy.

$\mathrm{H} 1 \mathrm{~b}$ : customers' service emphasis is effective on adoption of competitor orientation strategy.

Price-conscious customers in assessing the value of a firm's market offerings weigh most heavily on what they must pay. The needs of such customers are relatively predictable because they generally focus on price. So it is obvious that the strategic focus should be on price. To achieve a competitive advantage in price-sensitive markets, a firm must continually monitor its own operations in search of cost advantages. The firm should be also attentive to its competitors to determine their sources of cost advantage (Day and Wensley, 1988).A firm can make correct pricing decisions only after getting a clear idea of its cost position in a competitive market (Porter, 1985). Therefore, when customers strongly emphasize on price, the firm should adopt competitor orientation strategy in the market. In contrast, for price-conscious customers, firms can give up continuous and extensive monitoring of their customers because such activities are expensive (Day and Wensley, 1988). Therefore,

H1c: Customers' price emphasis is not effective on adoption of customer orientation strategy.

H1d: Customers' price emphasis is effective on adoption of competitor orientation strategy.

\section{Market orientation and competitive advantage}

The existence of relationship between market orientation and business performance is well-established (Greenley, 1995; Hooley et al., 2000; Langerak, 2001; Cano et al., 2004; Zhou et al., 2005; Gainer and Padany, 2005; Kara et al., 2005; Bhuian et al., 2005; Hult et al., 2005; Kirca et al., 2005). So this study focuses on the processes through which market orientation affects performance and shows how customer and competitor orientations differentially affect Iran insurance company's ability to achieve competitive advantage, which consequently affects market and financial performance. Competitive advantage refers to the comparative positional superiority in the marketplace that makes a firm to outperform its rivals (Porter,1985). In this study, in competitive advantage column, Miller's division is used (that is, innovation differentiation advantage and market differentiation advantage). An innovating firm emphasizes R\&D and the latest technologies in its new product development and aims at being the first to market with new products (Li, 2005; Miller, 1988). In contrast, a market differentiation advantage requires a firm to use the best marketing mix such as attractive packaging, good service, convenient locations, reliable products, and careful pricing to create a unique image, which does not imply a highest quality or most up-to-date product (Miller,1987).

Customer orientation emphasizes understanding customers so as to continuously create superior value for them. Because customers' needs change rapidly overtime, a customer orientation requires a clear understanding of target customers every time. A customeroriented firm by focusing on collecting, analyzing and disseminating information about customers can anticipate its customers' changing needs and respond to them 
through continuous innovation (Han et al., 1998). Moreover, when a firm clearly recognizes a gap between its customers' needs and its market offerings, the firm can direct resources toward filling that gap through successful innovations (Slater and Narver, 1998).

A customer orientation can also enable a firm to develop a competitive advantage based on market differentiation. A customer-oriented firm is knowledgeable about what customers desire, so by adjusting its marketing mix to the desires, it can make its market offerings more attractive for customers (Porter, 1985; Miller, 1988). Further, because the main objective of a customer-orientation is to achieve long-term customer satisfaction, a customer-oriented firm is highly motivated to provide products or services that uniquely fit the particular needs of its target customers (Slater and Narver, 1998). So below hypotheses would be tested in the insurance company.

H2a: customer orientation is effective on achieving innovation differentiation advantage.

$\mathrm{H} 2 \mathrm{~b}$ :customer orientation is effective on achieving market differentiation advantage .

A competitor oriented firm essentially focuses on identifying (1)current and potential competitors, (2) the technologies they utilize, and (3)whether they represent an attractive alternative from the perspective of the target customers (Narver and Slater, 1990). Then, in short, a competitor oriented firm assumes its rivals as a frame of reference and identifies its own advantages and disadvantages by analyzing them. A competitor-oriented firm could internalize a competitor's strengths by imitation or lose its effect by product innovation ( $\mathrm{Li}$ and Calantone, 1998). Competitor orientation appears to have doubleedged effects on innovation; competitor oriented firms watch competitors closely, match their innovations quickly and attempt to understand both the short-term strengths and weaknesses and long-term capabilities and strategies of current and potential competitors. Therefore, through a better understanding of its relative standing in the marketplace, a competitor-oriented firm can create a competitive advantage with continuous product innovation (new products with little improvements). A competitor-oriented firm, to decrease the high cost of product innovation, may simply choose to imitate its competitors rather than develop new products and services (Zhou et al,2008). When an asset is a resource in one environment can become a non-resource in another if it no longer contributes toward the creation of value in the firm's market offering (Hunt and Morgan, 1995). Empirical research by Lukas and Ferrell (2000) indicates that competitor-oriented firms tend to present the market with "me-too" products and avoid "new-to-theworld" innovations. Then these conflicting effects of competitor orientation on innovation may cancel each other, resulting in a non- relationship between competitor orientation and innovation differentiation advantage.

Because a competitor oriented firm emphasizes on matching exactly with competitors, so it identifies its capacities and offerings with those of its competitors (Day and Wensley, 1988). By focusing on its competitors, a firm may be unaware of its real interest, which may lead to inconsistent strategies and behaviors and consequently, unstable product offerings (Armstrong and Collopy, 1996). Furthermore, a competitor-oriented firm tends to assume that everything the competitors have done is correct, but may some products or services are uniquely fitted to a particular place and time and they will be unsuccessful if they be offered in different conditions (Hamel and Prahalad, 1994). Therefore, competitororiented firms may have difficulty in developing a market differentiation advantage.

H2c: firm's competitor orientation is not effective on achieving innovation differentiation advantage.

$\mathrm{H} 2 \mathrm{~d}$ : firm's competitor orientation is not effective on achieving market differentiation advantage.

\section{Competitive advantage and firms' performance}

Existing literature has well-established the positive effect of competitive advantage on performance, because a firm can outperform its competitors by competitive advantage. Zhou suggested that competitive advantage enhances firm's financial performance indirectly through improving market performance (2008). Market performance refers to the firm's ability to satisfy and retain customers by offering quality products and services; financial performance reflects the firm's profitability and market impact (Moorman and Rust, 1999). Indicators of market performance include customer satisfaction, product / service quality, customer retention, and customer loyalty, and typical indicators of financial performance are costs, sales revenue, profitability and market share (Moorman and Rust, 1999). An innovation advantage by the latest technology provides superior value for customers through the most up-to-date and innovative product offerings ( $\mathrm{Li}$, 2005). This value creation for customers will make customers more satisfied and loyal; and they will perceive the market offering have higher quality (Zeithaml, 1988).

Similarly, market differentiation advantage by specifically fitting marketing mixes to target customers has successfully created unique images for market offerings and, thus can increase the levels of customers' loyalty and satisfaction (Miller, 1988). In the final stage a firm's market performance will positively affect its financial performance. Because loyal customers are less sensitive to price changes, firms can command premium prices or sell more of their products at a given price, leading to a higher profit or market share (Porter, 1985). 
The positive reputation that results from higher levels of market performance enables the firm to attract new customers, introduce new products, decrease the costs of servicing previous customers and tolerate short-term environmental fluctuations more easily (Zhou et al., 2008). So customers' loyalty and satisfaction is a key mediator between competitive advantage and financial performance. That is, competitive advantage enhances financial performance indirectly through increasing market performance.

H3a: Innovation differentiation advantage is effective on market performance.

$\mathrm{H} 3 \mathrm{~b}$ : Market differentiation advantage is effective on market performance.

H3c: Market performance is effective on financial performance.

\section{THE RESEARCH METHODOLOGY}

\section{Population}

This study sought to choose respondents who can be expected to have the best knowledge about the strategy selection process and financial performance. To test the hypotheses, this study selects the service industry of Iran Insurance as empirical setting. The population includes all of the managers and employees of "Iran central insurance", the main firm for selecting insurance missions, goals and major strategies and all of the managers and employees of "Asia insurance " central branch and "Iran insurance" central branch, which are two dominant state-owned insurance firms in Iran. Because this population is small and limited, it is about 200 people, and for arising result reliability, questionnaires are delivered by census. The frequency distribution of the population in regard to sex includes 35\% women and 65\% men. Even though the performance statistics of this industry in our country does not show desirable condition, the perspective is promising. Fars News said insurance penetration coefficient in Iran is $1.3 \%$. When it is compared with the global coefficient (7.5\%), it shows great differences. In recent years insurance industry in Iran had some important changes such as making tariffs free and privatization. It is obvious that the first one is the requirement for the second. Because if there were a lot of private companies with fixed prices, there would be no competition among them in price and the base of competing is only in giving better services .

\section{Measures}

Data were obtained by standardized questionnaire of Zhou's essay called "Market orientation, competitive advantage and performance: A demand- based perspective" in 2008. It has 27 Items in a four separate focal constructs (customer value, market orientation, competitive advantage and firms' performance). They used this questionnaire for testing the same conceptual model in worldwide hotel industry. Supplementary information was also included from studying numerous essays .

\section{Validity and reliability}

The basic requirement for a good measurement is content validity, which means that the measurement items in an instrument cover the major content of a construct (Churchill, 1979). So these items were reviewed by fifteen experts including university professors and theoreticians who confirmed this questionnaire. For measuring the reliability, the questionnaire is pretested by distributing 20 among twenty "Iran insurance" central branch employees. Alpha -cronbach test was calculated. The extent of $81 \%$ demonstrated adequate validity.

\section{DATA ANALYSIS}

\section{Goodness of fit index}

The data were analyzed by using LISRE, a software package based on structural equation modeling (SEM) technique. Assessment of fit is a basic task in SEM modeling: forming the basis for accepting or rejecting models. Assessment of fit essentially calculates how similar the predicted data are to matrices containing the relationships in the actual data (Kaplan, 2000). One of the more commonly used measures of fit is Chi square /degree of freedom $\left(x^{2} / \mathrm{df}\right)$, that is a fundamental measure used in the calculation of many fit measures. Due to its sensitivity to the sample size, the relative chi-square is used. It should be 3 o less for an acceptable model (Tomer and Pugesek, 2003). The other fit measures used in this paper are as follows: Root mean square error of approximation (RMSEA), Goodness of fit index (GFI), Adjusted Goodness of fit index(AGFI), Non-normed fit index (NNFI), Comparative fit index (CFI). The rate of each index is seen in Table 1.RMSEA is lower than 0.05 and GFI, AGFI, NNFI and CFI are higher than 0.90. They demonstrate that the confirmatory model fit the data satisfactorily.

\section{Path analysis diagram method of structural equation modeling}

Structural equation modeling (SEM) is a statistical technique for testing and estimating causal relations using a combination of statistical data and qualitative causal assumptions (Wright, 1921; Haavelmo, 1943; Simon, 1953; Pearl, 2000). Path diagrams play a fundamental role in structural modeling. Path diagrams are like flowcharts. They show variables interconnected with lines that are used to indicate causal flow. One can think of a path diagram as a device for showing which variables cause changes in other variables (Kaplan, 2000). Confirmatory measurement model which is used in this research is designed in a linear diagrammatic form. In these diagrams, observed variables are shown in square form and latent variables are shown in circle form. Every unilateral arrow in these diagrams shows the effect of one variable on the other one. This model has two parts; the first part has two latent variables. These two variables of the first part are exogenous constructs. The 
Table 1. Goodness of fit tests.

\begin{tabular}{cccccc}
\hline$x^{2} / \mathrm{df}$ & $\begin{array}{c}\text { Root mean square error } \\
\text { of approximation } \\
\text { (RMSEA) }\end{array}$ & $\begin{array}{c}\text { Goodness of fit } \\
\text { index (GFI) }\end{array}$ & $\begin{array}{c}\text { Adjusted } \\
\text { Goodness of fit } \\
\text { index (AGFI) }\end{array}$ & $\begin{array}{c}\text { Non-normed fit } \\
\text { index (NNFI) }\end{array}$ & $\begin{array}{c}\text { Comparative fit } \\
\text { index (CFI) }\end{array}$ \\
\hline 0.48 & 0.04 & 0.92 & 0.91 & 0.91 & 0.92 \\
\hline
\end{tabular}

questionnaire items, from Q1 to Q6, are observed variables and the two elements of service emphasis and price emphasis are latent variables that are shown in circle forms. In the second part, there are six latent variables. The questionnaire items, from Q7 to Q27, are observed variables and the elements of customer orientation, competitor orientation, innovation differentiation, market differentiation, market performance and financial performance are latent variables. These two parts are connected to each other by a structural model. This structural model shows the conceptual model of this research. Service emphasis and price emphasis that are measured by Q1-Q6 are independent variables and customer orientation, competitor orientation, innovation differentiation, market differentiation, market performance and financial performance that are measured by Q7-Q27 are dependent variables (Table 2, Figure 2).

\section{Testing hypotheses}

The specification of the model consists of the transformation of the verbal hypotheses into a series of causal equations or a path diagram. Three indexes were given for every equations (1) non- standardized parameters (2) Standard error (3) T test; non - standardized parameters should be at least twice as much as standard error and Tvalue should not be between -1.96 to +1.96 , then hypotheses will be meaningful (Hair et al. , 2006). Figure 3 shows structural model of the study for confirming the hypotheses in T-value.

In analyzing $\mathrm{H}_{1} \mathrm{a}$, T-value is out of range of -1.96 and +1.96 and non - standardized parameters is twice as much as standard error, so the correlation between service emphasis and customer orientation is confirmed. In analyzing $\mathrm{H}_{1} \mathrm{~b}$ the measures show the correlation between service emphasis and competitor orientation is confirmed. As anticipated in $\mathrm{H}_{1}$ C T-value $=-0.43$ ratifies this hypothesis that there is no correlation between price emphasis and customer orientation. But in analyzing $\mathrm{H}_{1} \mathrm{~d}$ Tvalue $=-1.09$ (it is between -1.96 and +1.96 ) shows there is no correlation between price emphasis and competitor orientation, so $\mathrm{H} 1 \mathrm{~d}$ is rejected. In analyzing $\mathrm{H}_{2} \mathrm{a}$ and $\mathrm{H}_{2} \mathrm{~b}$ the measures show the correlation between customer orientation with innovation and market differentiation is confirmed. As anticipated in $\mathrm{H}_{2} \mathrm{C}$ and $\mathrm{H}_{2} \mathrm{~d}$ the measures ratify these hypotheses that there are no correlation between competitor orientation with innovation and market differentiation. But in analyzing $\mathrm{H}_{3} \mathrm{a}$ and $\mathrm{H}_{3} \mathrm{~b}$ $\mathrm{T}$-value (it is between -1.96 and +1.96 ) shows there is no correlation between innovation and market differentiation with market performance, so these hypotheses are rejected. Finally analyzing $\mathrm{H} 3 \mathrm{c}$ shows the correlation between market performances with financial performance is confirmed. The results are shown in Table 3.

\section{Conclusion}

This study analyzed Iran insurance's policy and determined the process of strategy selection and compared it with the ideal situation that Zhou explained in his essay called "Market orientation, competitive advantage and performance: A demand-based perspective". First, this research represents the first effort that takes a demandbased perspective to examine how customer value heterogeneity affects a firm's market orientation and consequently its competitive advantage and organizational performance in a command economy. The findings generally support the basic tenet of the demandbased view that customer heterogeneity significantly influences a firm's strategic choices (Zhou et. al., 2008, Adner and Zemsky, 2006; Desarbo et al., 2001). In particular, this paper analyzed the process of strategy selection in Iran insurance as a command economy and compared it with the ideal situation that Zhou explained in his essay to find the deficiencies. It finds that if Iran insurance perceives its customers as emphasizing what they "get" (that is, they emphasize service), the firm is more likely to adopt both a customer and a competitor orientation. In contrast, if the firm thinks its customers as valuing what they must "give up" (focusing on price), this company tends to develop no purposeful strategy in the market. This is a weak point for this company, because according to Zhou, in this situation, the best strategy to respond to the market is competitor orientation. As in such a market, that customer gives a great attention to the price, customer orientation increases the prices. To target these customers, Iran insurance company should reach to a competitive price by adopting competitor orientation strategy. Second, this research analyzed how customer and competitor orientations in Iran insurance company affect innovation and market differentiation advantage. Previous studies suggest that customer and competitor orientations are two distinct aspects of market orientation (Lukas and Ferrell, 2000) and some have 
Table 2. The Items of measurement in the questionnaire (Q1-Q27: observed variables; latentariables).

\begin{tabular}{ll}
\hline No & Measurement items \\
\hline & Customer value \\
Service emphasis \\
1. Our customers belong to a very exclusive class whose needs are unique .=Q1 \\
2. Our customers are very particular about the service they receive .=Q2 \\
3. We would not succeed in this market without providing excellent service.=Q3 \\
1. Orice emphasis \\
2. There is great pressure on us to have competitive prices .=Q5 \\
3. Our customers choose insurance companies based on prices .=Q6
\end{tabular}

\section{Market orientation} Customer orientation

1. Our insurance company believes in total commitment to the customer $=\mathrm{Q} 7$

2. Our compensation plan rewards employees and managers who are committed to customer satisfaction. $=\mathrm{Q} 8$

3. We regularly measure customer satisfaction .=Q9

4 We spend a great deal of effort trying to understand customer needs. $=\mathrm{Q} 10$

5 We do whatever it takes to create value for our customers .=Q11

6 We continuously monitor our customers' needs .=Q12 Competitor orientation

1. Our sales and marketing people share competitor information with other departments. $=\mathrm{Q} 13$

2. We respond rapidly to our competitors' actions .=Q14

3. We are constantly looking for opportunities to gain an advantage over our competitors $\quad=Q 15$

\section{Competitive advantage} Innovation differentiation

1 We are constantly investing in generating new capabilities that give us an advantage compared to our competitors.=Q16

2 If ever there was a new way of serving customers, our company would be able to offer that.=Q17 Market differentiation

1 1.It is difficult for our competitors to imitate us .=Q18

2 2. Our services are unique and nobody but our company can offer them .=Q19

3 It took us several years to build our brand name reputation -nobody can easily copy that.=Q20

4 Our advantages are embodied in the company and not in individuals -nobody can copy us by stealing our employees away from us .=Q21

$5 \quad$ Nobody can copy our corporate routines, processes and culture. Q22

\section{Organizational performance}

Market Performance: Compared to your direct competitors, how well did your hotel do in terms of the following measures?

1 Service quality=Q23

2 Customer satisfaction $=\mathrm{Q} 24$

Financial Performance: Compared to your direct competitors, how well did your hotel do in terms of the following measures?

1 Occupancy $=$ Q25

2 Gross operating profit $=\mathrm{Q} 26$

Source : Zhou KZ. Market orientation, competitive advantage and performance (2008).

posited that a competitor orientation can even be antithetical to a customer orientation (Deshpande et al., 1993). Zhou (2008), after the examination of the market orientation-competitive advantage link, revealed why this case may happen. He suggested that customer orientation seems to be the dominant factor responsible for 
Table 3. T value, standard error and non standardized parameters of path diagrams.

\begin{tabular}{llcccc}
\hline Hypotheses & Path & $\begin{array}{c}\text { T- } \\
\text { value }\end{array}$ & $\begin{array}{c}\text { Standard } \\
\text { error }\end{array}$ & $\begin{array}{c}\text { Non standard } \\
\text { parameters }\end{array}$ & $\begin{array}{c}\text { Testing } \\
\text { hypotheses }\end{array}$ \\
\hline $\mathrm{H}_{1} \mathrm{a}$ & Service emphasis - Customer orientation & 2.17 & 0.24 & 0.52 & Confirmed \\
$\mathrm{H}_{1} \mathrm{~b}$ & Service emphasis- Competitor orientation & 4.10 & 0.23 & 0.95 & Confirmed \\
$\mathrm{H}_{1} \mathrm{C}$ & Price emphasis -Customer orientation & 0.43 & 0.075 & -0.032 & Confirmed \\
$\mathrm{H} 1 \mathrm{~d}$ & Price emphasis- Competitor orientation & 1.09 & 0.094 & -0.10 & Rejected \\
$\mathrm{H}_{2} \mathrm{a}$ & Customer orientation-Innovation differentiation & 2.03 & 0.23 & 0.46 & Confirmed \\
$\mathrm{H}_{2} \mathrm{~b}$ & Customer orientation- Market differentiation & 2.02 & 0.37 & 0.68 & Confirmed \\
$\mathrm{H}_{2} \mathrm{C}$ & Competitor orientation-Innovation differentiation & 0.36 & 0.15 & -0.052 & Confirmed \\
$\mathrm{H}_{2} \mathrm{~d}$ & Competitor orientation- Market differentiation & 1.20 & 0.16 & 0.19 & Confirmed \\
$\mathrm{H}_{3} \mathrm{a}$ & Innovation differentiation- Market performance & 1.21 & 0.12 & 0.14 & Confirmed \\
$\mathrm{H}_{3} \mathrm{~b}$ & Market differentiation- Market performance & 0.64 & 0.27 & 0.72 & Rejected \\
$\mathrm{H}_{3} \mathrm{C}$ & Market performance- Financial performance & 4.60 & 0.13 & 0.62 & Confirmed \\
\hline
\end{tabular}

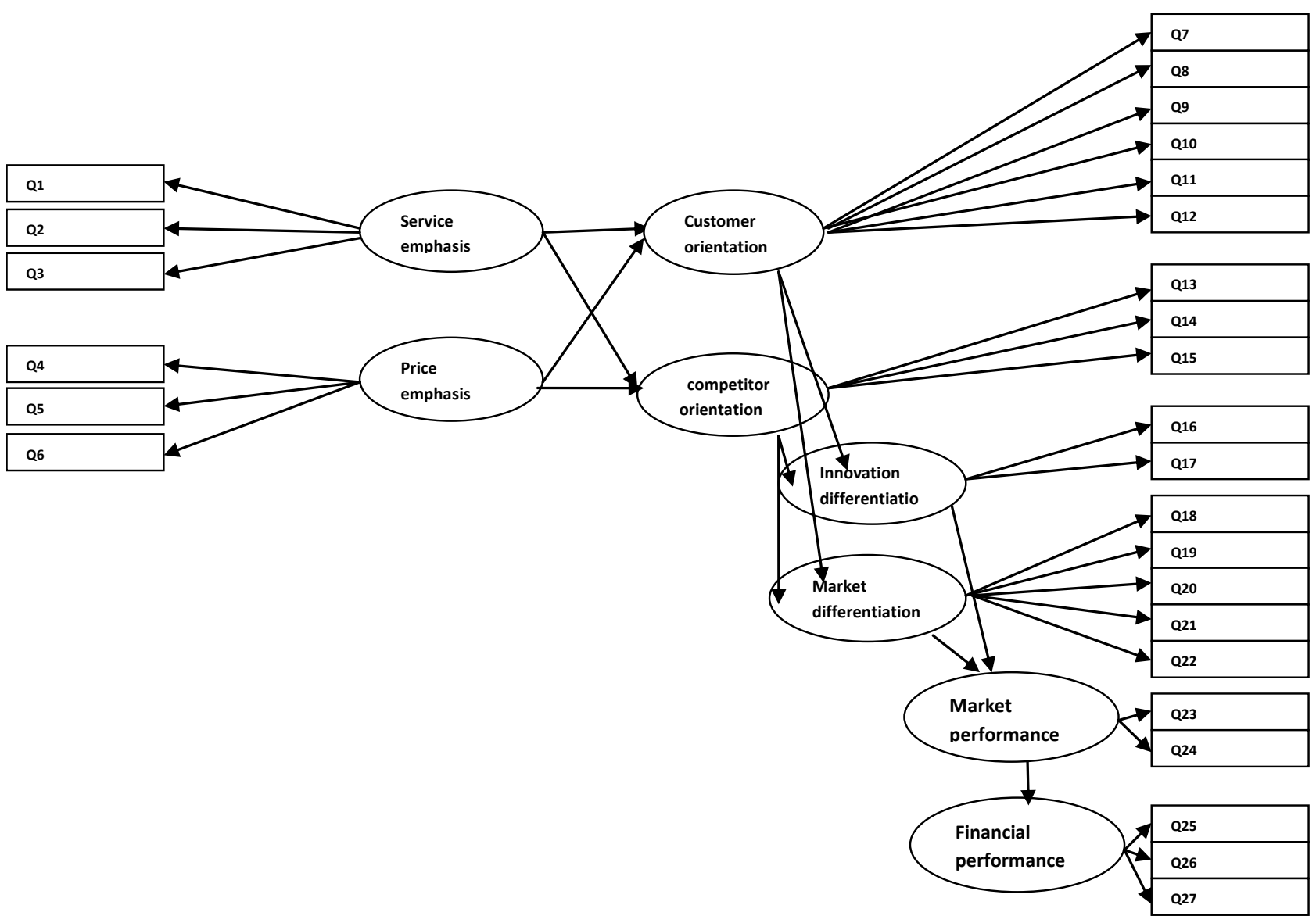

Figure 2. The measurement model of the study for confirming hypotheses. Chi-square $=4.37 \quad d f=9 ; P-v a l u e=0.00000$; RMSEA $=0.04$.

achieving a competitive advantage. Customer orientation is not only linked to a firm's innovation differentiation advantage, but also associated with a greater market differentiation advantage. Competitor orientation, in contrast, has no impact on a firm's market differentiation advantage and innovation differentiation advantage. Overall, the results of this paper confirmed Zhou's findings. It showed the seemingly counter-intuitive nature 


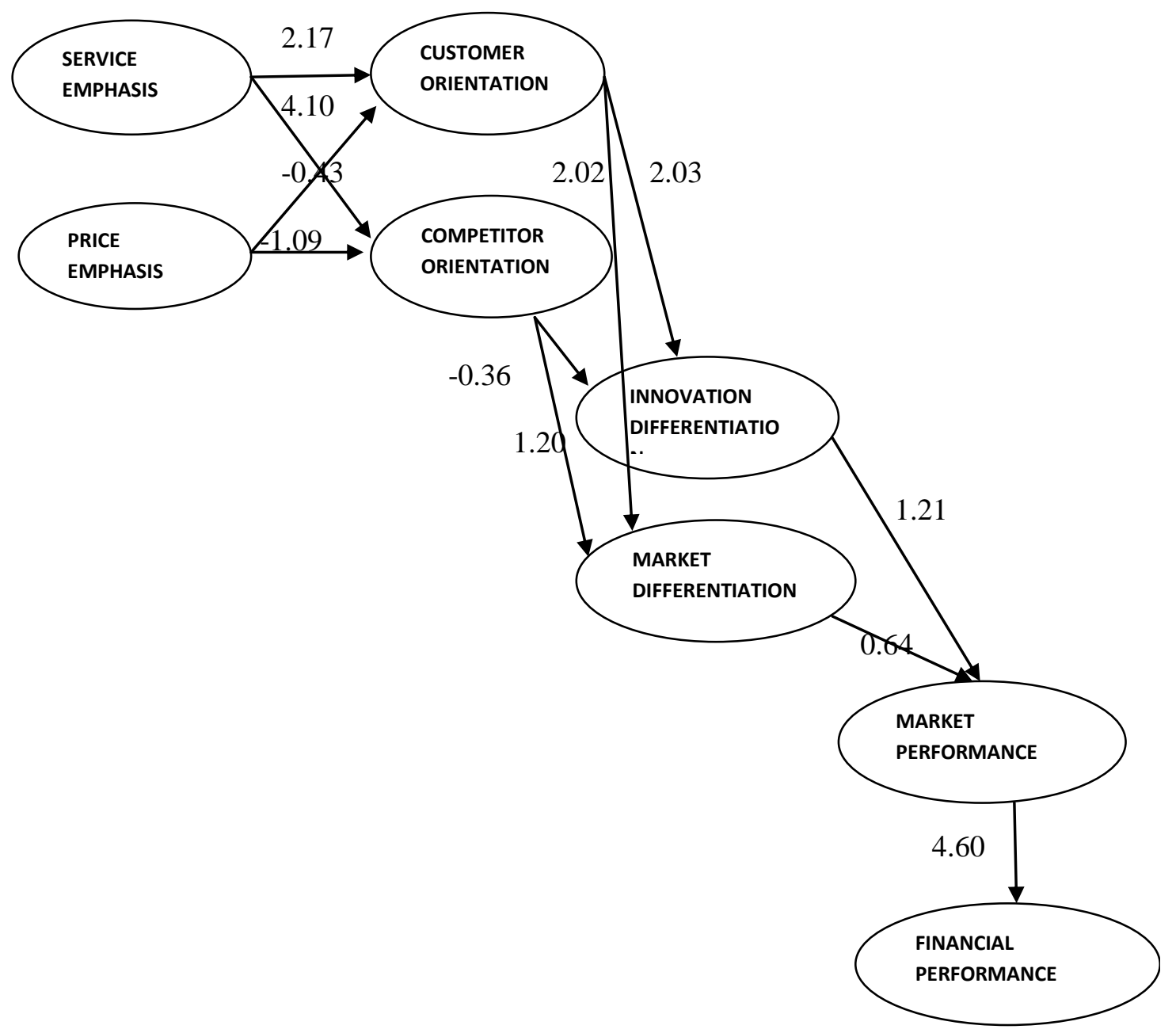

Figure 3. Structural model for testing the hypotheses of the study in T-value. Chi - square $=4.37 \quad \mathrm{df}=9 \quad \mathrm{P}$ value $=0.00000 ;$ RMSEA $=0.04$.

of customer and competitor orientations to each other for reaching competitive advantage. Therefore, customer orientation appears to be a better choice for Iran insurance to achieve differentiation advantages.

The third contribution is that, in addition to financial performance, this paper analyzed market performance. This dimension of performance considers customer reactions to the firm's market offerings. That is competitive advantage affects financial performance indirectly through market performance. These results indicate that a firm specializing in innovation or market differentiation can attain higher levels of market performance (that is superior service quality and higher customers' satisfaction). It means making customers happy has an important role in enhancing financial performance of service firms (Zhou et al., 2008). However, our findings showed that neither innovation nor market advantage has direct significant impact on market performance. Unfortunately, in particular, this study found that neither innovation differentiation nor market differentiation advantages in Iran insurance follow enhancing customer satisfaction and market performance; maybe this result is the best representative of Hunt and Morgan premise that the single most important macroeconomic phenomenon of the twentieth century has undoubtedly been the collapse of planned or command economies which were premised on cooperation among state-owned firms under the direction of a central planning board, and the concomitant triumph of market based economies which are premised on competition among self-directed, privately owned firms. As command economy misallocate resources because of lack of signals from the marketplace as to where planners should deploy resources (1995) maybe $R \& D$ department has a long distance with customer that should be shortened. The representatives are the frontiers of Iran insurance company, so they can recognize customer's needs and desires more easily. R\&D circle should extend itself to these frontiers and translate 
these information to innovation and market differentiation. Therefore, Iran insurance company should pay special attention on how to deliver its services and win customers' satisfaction. Finally, most of the population of this research believed that they have no role in decision making and strategy selection. Iran insurance company should not be so centralized, because selecting strategy without paying attention to customer value will not lead to competitive advantage. Iran insurance company can divide its customers into three groups by extracting information of the representatives: golden customers, silver customers and bronze customers. Then some special services should be considered for each group in order to gain two aims: reserve golden customers and motivate silver customers and bronze customers to come into golden customers.

\section{LIMITATIONS AND FURTHER RESEARCH}

As an initial enquiry of a complex phenomenon, this study, like any scientific research, is subject to several limitations. First this study assesses how customer value perceived by firms affects firms' orientation, but firms' orientations and strategies can also influence customer values. Analyzing the reciprocal relation between them is recommended for further research. Time span was another major limitation of this study. Customer value changes overtime. How those changes affect a firm's orientation and competitive advantage requires further research, especially using longitudinal designs. Third, this paper does not examine one important aspect of market orientation that is inter-functional coordination. Analyzing its impact on competitive advantage and performance is recommended for further research. Finally, this paper does not examine one important aspect of competitive advantage, that is, cost advantage. A competitororientation may enable a firm to gain a cost advantage. Analyzing the impact of market orientation on cost advantage is also recommended for further research.

\section{REFERENCES}

Adner R, Zemsky P (2006). A demand-based perspective on sustainable competitive advantage. Strateg. Manage. J. 27:215-239.

Armstrong JS, Collopy F (1996). Competitor orientation: effects of objectives and information on managerial decisions and profitability. J. Mark Res. 33:188-199.

Barney JB (1991). Firm resources and sustained competitive advantage. J. Manage. 17:99-120.

Bhuian SN, Menguc B, Bell SJ (2005). Just Entrepreneuria Enough: the Moderating Effect of entrepreneurship on the relationship between market orientation and performance, J. Bus. Res. 58:9-17.

Cano CR, Carrillat FA, Jaramillo F (2004). A Meta-analysis of the Relationship between Market Orientation and Business Performance: Evidence from Five Continents, Int. J. Res. Market. 21:179-100.

Churchill GA (1979). A paradigm for developing better measures of marketing constructs. J. Market. Stud. 16:12-27.

Day G, Nedungadi P (1994). Managerial representations of competitive advantage. J. Market. 58:31-44
Day GS, Wensley R (1988). Assessing advantage : a framework for diagnosing competitive Superiority. J. Mark. 52:31-44.

Desarbo WS, Jedidi K, Sinha I (2001). Customer value analysis in a heterogeneous market. Strateg. Manage. J. 22:845-857.

Gainer B, Padanyi P (2005). The relationship between market-oriented activities and market-oriented culture: implications for the development of market orientation in non-profit service organizations, J. Bus. Res. 58:854-862.

Greenley GE (1995). Market orientation and company performance:Empirical evidence from UK companies, Br. J. Manage. 6:1-13.

Haavelmo T (1943). The statistical implications of a system of simultaneous equations, Econometrica 11:1-2.

Hair JF, William CB, Babin BJ, Anderson RE, Tatham RL (2006). Multivariate Data Analysis ,Pearson University Press, Newjersey.

Hamel G, Prahalad CK (1994). Competing for the Future Boston, MA: Harvard Business School Press.

Han JK, Kim N, Srivastava RK (1998). Market orientation and organizational performance: is innovation a missing link? J. Mark. 62:30-45.

Hooley G, Cox T, Fahy J, Shipley D, Beracs J, Fonfara K, Snoj B (2000). Market Orientation in the Transition Economies of Central Europe: Test of the Narver and Slater Market Orientation Scales. J. Bus. Res. 50:273-285.

Hult GTM, Ketchen Jr. DJ, Slater SF (2005). Market orientation and performance: an integration of disparate approaches. Strateg. Manage. J. 26:259-276.

Hunt SD, Morgan RM (1995). The comparative advantage theory of competition J. Market. 59(2); ABI/INFORM Research.

Kaplan D (2000). Structural Equation Modeling: Foundations and Extensions. SAGE, Adv. Quant. Techniques Soc. Sci. Series Vol. 10, ISBN 0-7619-1407-2.

Kara A, Spillan JE, DeShields Jr. OW (2005).The Effect of a Market Orientation on Business Performance: A Study of Small-Sized Service Retailers Using MARKOR Scale, J. Small Bus. Manage. 43(2): $105-118$.

Keith RJ (1960). The marketing revolution. J. Mark. 24:35-38.

Kirca AH, Jayachandran S, Bearden WO (2005). Market orientation: a meta-analytic review and assessment of its antecedents and impact on performance. J. Mark. 69(2):24-41.

Kohli AK, Jaworski BJ (1990). Market orientation: the construct, research propositions, and managerial implications. J. Mark. 54(2):1 18.

Kohli AK, Jaworski BJ (1993). Market orientation, antecedents and concequences, J. Market. 57:53-70.

Langerak $F$ (2001). Effects of market orientation on the behaviours of salespersons and purchasers, channel relationship, and the performance of manufacturers. Int. J. Res. Market. 18:221-234.

$\mathrm{Li} \mathrm{JJ} \mathrm{(2005).} \mathrm{The} \mathrm{formation} \mathrm{of} \mathrm{managerial} \mathrm{networks} \mathrm{of} \mathrm{foreign} \mathrm{firms} \mathrm{in}$ China: the effects of strategic orientations. Asia Pac. J. Manage. 22:423-443.

Li T, Calantone RJ (1998). The impact of market knowledge competence on new product advantage: Conceptualization and empirical examination. J. Mark. 62:13-29.

Lukas B, Ferrell OC (2000). The effects of market orientation on product innovation. J Acad. Mark. Sci. 28:239-247.

Miller D (1987). The structural and environmental correlates of business strategy. Strateg. Manage. J. 8:55-76.

Miller D (1988). Relating Porter's business strategies to environment and structure. Acad. Manage. J. 31:280-308.

Moorman C, Rust RT (1999). The role of marketing. J. Mark. 63:97-180.

Slater SF, Narver JC (1994a). Market orientation, customer value and superior performance. Bus. Horizons 2:2-22.

Slater SF, Narver JC (1994b). Does competitive environment moderate the market orientation-performance relationship? J. Market. 58:46-55.

Slater SF, Narver JC (1990). The effect of a market orientation on business profitability. J. Mark. 54:20-35.

Slater SF, Narver JC, Tietje B (1998). Creating a Market Orientation. J. Market Focused Manage. 2:241-255.

Pearl J (2000). Causality: Models, Reasoning, and Inference. Cambridge University Press. ISBN 0521773628. 
Porter M (1985). Competitive Advantage. New York: Free Press.

Simon H (1953). Causal ordering and identifiability. In: Hood WC, Koopmans TC. Stud. Econom. Method. New York: Wiley pp.49-74.

Tomer A, Pugesek BH (2003). Guidelines for the implementation and publication of structural equation models. In: Pugesek $\mathrm{BH}$, Applications in Ecological and Evolutionary Biology, Cambridge University Press, Cambridge.

Webster Jr. FE (1994). Executing the marketing concept. Market. Manage. 3(1):9-16

Woodruff RB (1997). Customer value: the next source for competitive advantage. J. Acad. Mark. Sci. 25:139-153.

Wright Sewall S (1921). Correlation and causation. J. Agric. Res. 20:557-585
Zeithaml VA (1988). Consumer perceptions of price, quality, and value: a means-end model and synthesis of evidence. J. Mark. 52:2-22.

Zhou KZ, Yim CK, Tse DK (2005). The effects of strategic orientations on technology and market-based break through innovations. J. Mark. 69:42-60.

Zhou KZ, James RB, Chekitan SD (2008). Market orientation, Competitive advantage and Performance: A demand based perspective. J. Bus. Res. 62(11):1063-1070. 